\title{
Type II NKT cells differentially regulate CD4 T cell subsets
}

\author{
Faith C Robertson ${ }^{1}$, Xiuju Lu ${ }^{2 *}$, Masaki Terabe1 ${ }^{1,1}$, Jay A Berzofsky ${ }^{1}$ \\ From Society for Immunotherapy of Cancer 29th Annual Meeting \\ National Harbor, MD, USA. 6-9 November 2014
}

Natural killer T (NKT) cells lie at the interface between the innate and adaptive immune systems and are important mediators of tumor immunosurveillance. This CD1d-restricted lymphoid population recognizes lipid antigen and can rapidly produce an array of cytokines and chemokines to modulate the host immune response. In tumor immunity, two NKT cell subsets (type I and type II) have contrasting roles in which they not only distinctly impact innate and adaptive immune cell populations, but also cross-regulate one another. Type I NKT cells are usually associated with the promotion of tumor immunity whereas type II NKT cells seem to suppress it. Previous studies showed that type II NKT cells negatively impact $\mathrm{CD}^{+} \mathrm{T}$ cells; however, little is known about their effect on $\mathrm{CD}^{+} \mathrm{T}$ helper subsets. In this study, we investigated how $\mathrm{CD} 4^{+} \mathrm{T}$ cell subsets are affected by type II NKT cells activated with sulfatide, an endogenous glycolipid antigen known to activate type II NKT cells. Naïve ovalbumin (OVA) specific CD4 ${ }^{+}$ $\mathrm{T}$ cells isolated from DO11.10 transgenic mice were either tested ex vivo, or polarized in vitro into $\mathrm{T}$ helper subsets (Th1, Th2 and Th17). CFSE dilution and ELISAs were used to assess $\mathrm{CD} 4^{+} \mathrm{T}$ cell proliferative and cytokine responses upon antigenic stimulation in the presence or absence of sulfatide-activated type II NKT cells. We found that activated type II NKT cells significantly inhibited proliferation of naïve $\mathrm{CD} 4^{+} \mathrm{T}$ cells. The differentiated activated/memory subsets appeared to be less susceptible to such suppression. Ongoing elucidation of these interactions and mechanisms may not only augment our understanding of $\mathrm{CD} 4^{+} \mathrm{T}$ cell regulation, but also improve our capability to utilize type II NKT cells for clinical applications.

${ }^{2}$ Division of Target Discovery, Otsuka Maryland Medicinal Laboratory, Rockville, MD, USA

Full list of author information is available at the end of the article
Authors' details

'Vaccine Branch, Center for Cancer Research, National Cancer Institute, National Institutes of Health, Bethesda, MD, USA. ${ }^{2}$ Division of Target Discovery, Otsuka Maryland Medicinal Laboratory, Rockville, MD, USA.

Published: 6 November 2014

doi:10.1186/2051-1426-2-S3-P233

Cite this article as: Robertson et al:: Type II NKT cells differentially regulate CD4 T cell subsets. Journal for ImmunoTherapy of Cancer 2014 2(Suppl 3):P233.
Submit your next manuscript to BioMed Central and take full advantage of:

- Convenient online submission

- Thorough peer review

- No space constraints or color figure charges

- Immediate publication on acceptance

- Inclusion in PubMed, CAS, Scopus and Google Scholar

- Research which is freely available for redistribution

Submit your manuscript at www.biomedcentral.com/submit
() Biomed Central
C BioMed Central

(c) 2014 Robertson et al.; licensee BioMed Central Ltd. This is an Open Access article distributed under the terms of the Creative Commons Attribution License (http://creativecommons.org/licenses/by/4.0), which permits unrestricted use, distribution, and reproduction in any medium, provided the original work is properly cited. The Creative Commons Public Domain Dedication waiver (http://creativecommons.org/publicdomain/zero/1.0/) applies to the data made available in this article, unless otherwise stated. 